\title{
Deferasirox Effect on Serum Ferritin in Iraq Patients with Hemoglobinopathies: A Single Center Experience
}

\author{
Khalaf Hussein Hasan ${ }^{1}$, Aspazija Sofijanova ${ }^{2 *}$, Luma Hassan ${ }^{3}$, Nasir Al-Allawi ${ }^{4}$ \\ ${ }^{1}$ Department of Pediatrics, College of Medicine, University of Duhok, Duhok, Iraq; ${ }^{2}$ University Children's Hospital, Ss Cyril and \\ Methodius University, Skopje, Republic of Macedonia; ${ }^{3} \mathrm{Jin}$ Pediatric Hematology and Oncology Center, Directorate of Health, \\ Duhok, Iraq; ${ }^{4}$ Department of Pathology, College of Medicine, University of Duhok, Duhok, Iraq
}

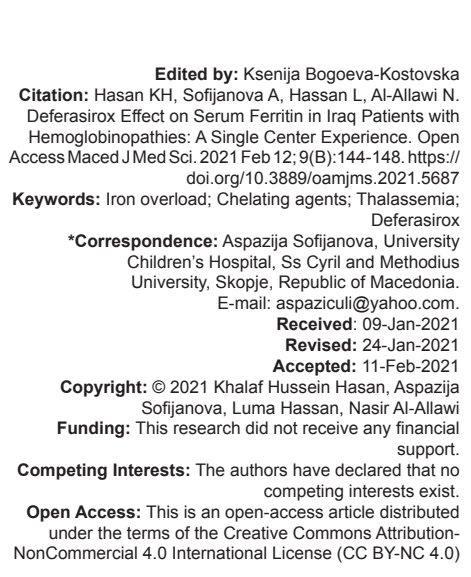

Abstract

BACKGROUND: The introduction of deferasirox as an oral iron chelator for hemoglobinopathies has been hailed by many as an important milestone in the management of iron overload in the latter disorders.

AIM: The objectives of the study were to evaluate the effectiveness of deferasirox in patients with hemoglobinopathies and to assess predictors of response.

METHODS: In this cross-sectional study, 160 patients diagnosed with hemoglobinopathies were included retrospectively from Jin hematology and oncology center in Duhok city, Iraqi Kurdistan. The Jin center offers patients with hemoglobinopathies clinical advice, examination, follow-up, treatment, and blood transfusions.

RESULTS: The median age of enrolled patients was 12 years (range 3-34 years), and included 86 females and 74 males. All patients were on deferasirox with a compliance rate of $77.5 \%$. Furthermore, $32.3 \%$ were on concomitant deferoxamine at their last follow-up. After a median follow-up of 2.1 years (range 1-4 years), there was a mean reduction of serum ferritin level of -478.7 overall and $-821.1 \mathrm{ng} / \mathrm{ml}$ in complaint patients (both being significant at $p$ of 0.042 and 0.001 , respectively). Univariate analysis revealed that older age at enrollment, and older age at starting therapy, and initial serum ferritin $(>3000 \mathrm{ng} / \mathrm{ml})$ were all significantly associated with more mean reduction in serum ferritin; while only the latter remained so by multivariate analysis $(p=0.04)$.

CONCLUSIONS: Deferasirox was found to be effective in reducing the level of serum ferritin among this cohort of hemoglobinopathy patients, to a degree comparable to that reported in other studies worldwide. Furthermore, there were significant associations between the reduction of serum ferritin level and age, age at starting treatment, drug compliance, and the initial serum ferritin levels.

\section{Introduction}

Blood transfusion constitutes the cornerstone of the management of symptomatic hemoglobinopathies [1]. Each blood unit adds 200$250 \mathrm{mg}$ of iron to body stores and since there is no physiological mechanism to remove the excess iron from the human body, iron overload would be inevitable [2]. As the iron storage capacity of macrophages and hepatocytes is exceeded, and the excess iron released to the plasma becomes beyond the capacity of transferrin, Non-Transferrin Bound Iron (NTBI) starts appearing. Thereafter, NTBI will be deposited in various tissues and reactive oxygen species are produced by its metabolism causing damage to these tissues, including: Cardiac muscles, hepatocytes, pancreatic, thyroid, parathyroid, and pituitary cells [3]. Hence, to counter iron overload several iron chelators were introduced over the past few decades including subcutaneous deferoxamine, oral defriprone, and more recently the oral Deferasirox [4]. Several studies over the past decade have revealed the relative safety and convenience of deferasirox, and its efficacy in reducing iron overload across a variety of anemias, as shown by reductions in serum ferritin, liver iron content, and cardiac iron [5], [6].

There is paucity of studies evaluating the efficacy of deferasirox in reducing serum ferritin in hemoglobinopathy Iraqi patients, [7], [8] despite the fact that it has been in regular use for several years in the country and provided freely to these patients by government. Thus, the current study was initiated to assess the efficacy of this iron chelator in reducing serum ferritin among patients with hemoglobinopathies registered at the thalassemia center in Northern Iraq.

\section{Patients and Methods}

A total of 160 patients diagnosed as hemoglobinopathies and receiving deferasirox were included retrospectively from Jin hematology and oncology center in Duhok city, Iraqi Kurdistan. The 
eligibility criteria included age in excess of 2 years and a treatment duration of at least 1 year. The patients with incomplete data were excluded from the study.

Patients had their medical records reviewed, and a detailed history and clinical examination performed at the time of enrollment. The data collected comprised age, gender, the number of blood units received per year, drug history including: dose, duration, compliance with the drug, history of the using other chelating agents, history of other drugs intake, as well as other associated illnesses. The following investigations were scrutinized: Serum ferritin, serum alanine transferase (ALT), and aspartate transaminase (AST) and creatinine at baseline level at the initiation of the drug therapy and at last follow-up.

The study was approved by the scientific and ethics committee at the college of medicine, University of Duhok, Iraq. Informed consent was obtained from all enrolled patients.

\section{Statistical analysis}

The data were entered into SPSS version 22 statistical package (IBM Corp, 2013). Analytic statistics included testing paired differences by the paired t-test, and examining differences between two independent groups using the unpaired t-test and among more than two groups using one-way analysis of variance (ANOVA). Pearson's correlation ( $r$ ) was used to test the association between the change in serum ferritin and clinical and laboratory findings. Multivariable binary logistic regression was used to determine the independent factors predicting the change in ferritin level, with measurement of risk as the adjusted odds ratio (OR); the independent variables used were the significant ones, plus those with p-value up to 0.250 in the univariate analyses (except diagnostic category where $p=0.272$ ); the dependent variable was decreased serum ferritin (coded zero) and increased serum ferritin (coded one). The significance level was set at $p<0.05$.

\section{Results}

The median age of the 160 enrolled patients was 12 years (range 3-34 years) with 74 males and 86 females. The majority of enrolled patients were $\beta$-thalassemia major (129 patients [80.6\%]), followed by sickle cell disease in 28 cases $(17.6 \%)$ and thalassemia intermedia in 3 cases (1.9\%). The median number of transfusion sessions received in the last year was 15 (range 0-27). The proportion of splenectomized patients was $42.5 \%$. All received Deferasirox (DFX) with a mean dose of $34.2 \mathrm{mg} / \mathrm{kg} /$ day at their last follow-up. The median duration of therapy with DFX was 2.1 years (range 1-4), while the median age at initiating therapy was 9 years (2-32 years). Full compliance with the drug was reported in 124 patients $(77.5 \%)$. Forty patients (32.3\%) were on concomitant Deferoxamine (DFO) with DFX at their last follow-up.

Table 1: A paired comparison of some laboratory findings before and after the administration of deferasirox $(n=160)$

\begin{tabular}{|c|c|c|c|c|c|}
\hline & Mean & SE & $\begin{array}{l}\text { Mean difference } \\
\text { (after - before) }\end{array}$ & $\begin{array}{l}95 \% \mathrm{Cl} \text { of } \\
\text { Difference }\end{array}$ & $\mathrm{p}^{*}$ \\
\hline \multicolumn{6}{|c|}{ Ferritin (ng/ml) [all patients) } \\
\hline Before & 5405.8 & 248.5 & -478.7 & $17.8-939.5$ & 0.042 \\
\hline After & 4927.1 & 280.1 & & & \\
\hline \multicolumn{6}{|c|}{ Ferritin (ng/ml) [in complaint patients] } \\
\hline Before & 5346.4 & 281.3 & -821.1 & $-1288.1-354.1$ & 0.001 \\
\hline After & 4525.3 & 286.4 & & & \\
\hline \multicolumn{6}{|l|}{ SGPT (u/l) } \\
\hline Before & 120.2 & 29.9 & -34.5 & $-24.2-93.3$ & 0.247 \\
\hline After & 85.6 & 4.3 & & & \\
\hline \multicolumn{6}{|c|}{ SGOT (u/l) } \\
\hline Before & 64.2 & 4.7 & 3.0 & $-8.6-2.5$ & 0.278 \\
\hline After & 67.2 & 4.6 & & & \\
\hline \multicolumn{6}{|c|}{ Creatinine (mg/dl) } \\
\hline Before & 0.42 & 0.01 & 0.02 & $-0.06-0.02$ & 0.316 \\
\hline After & 0.44 & 0.02 & & & \\
\hline
\end{tabular}

The study showed that the concentration of serum ferritin, and after a median follow-up of 2.1 years on therapy, was significantly decreased [Mean difference: $-478.7 \mathrm{ng} / \mathrm{ml}(\mathrm{p}=0.042)$. The degree of reduction and significance was more noticeable when the evaluation was restricted to the 124 complaint patients (mean difference $-821.1 ; p=0.001$; Figure 1 ). The study did not find any significant difference in the concentration of serum ALT, AST, or of serum creatinine (Table 1).

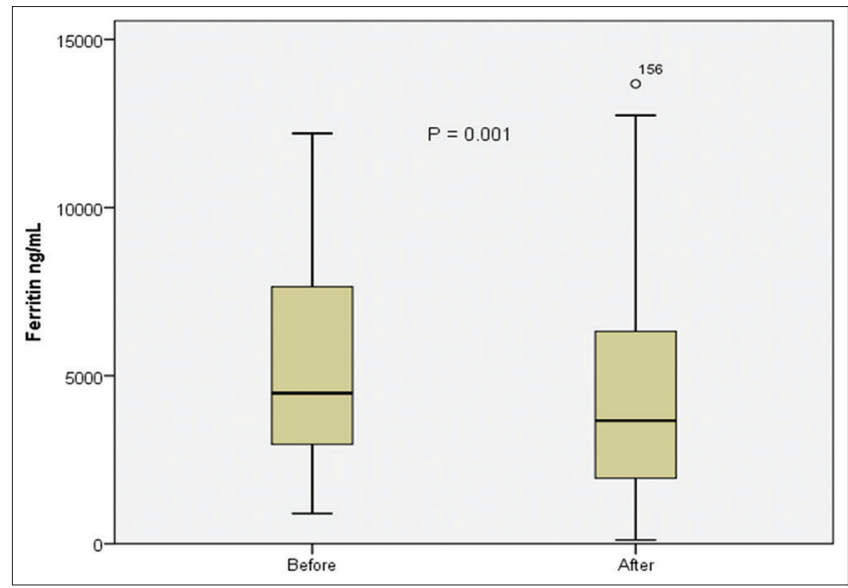

Figure 1: Changes in serum ferritin after a median follow-up of 2.1 years in Complaint patients

Correlation of serum ferritin change with various parameters among complaint enrollees: when the evaluation was restricted to 124 complaint patients, it was found that the change in the level of serum ferritin with the administration of DFX was significant in the age group ( $\geq 16$ years) in comparison to the age group (<16 years) [ $p=0.019$ ] (Table 2). Furthermore, age at starting therapy as a continuous variable correlated with change in serum ferritin ( $p=0.01)$ (Figure 2). Other significant variables include age at starting DFX, and initial Ferritin prior chelation $(p=0.01$ and 0.003 , respectively). Other parameters shown in Table 2 were not significantly associated with changes in serum ferritin. 
Table 2: Comparison between various parameters and degree of change in serum ferritin after a median of 2.1 year of DXT therapy in 124 complaint patients

\begin{tabular}{|c|c|c|c|c|}
\hline \multirow[t]{2}{*}{ Characteristic $(n=124)$} & \multirow[t]{2}{*}{$\mathrm{n}$} & \multicolumn{2}{|c|}{ Ferritin change } & \multirow[t]{2}{*}{$\mathrm{p}^{*}$} \\
\hline & & Mean & SE & \\
\hline \multicolumn{5}{|l|}{ Current age (years) } \\
\hline $3-15$ years & 91 & -490.7 & 258.9 & \multirow[t]{2}{*}{0.015} \\
\hline $16-34$ years & 33 & -1732.1 & 498.8 & \\
\hline \multicolumn{5}{|l|}{ Deferasirox Starting age (year) } \\
\hline $2-12$ & 88 & -433.3 & 256.1 & \multirow[t]{2}{*}{0.01} \\
\hline 13-32 & 36 & -1769.0 & 489.0 & \\
\hline \multicolumn{5}{|l|}{ Sex } \\
\hline Male & 56 & -1071.9 & 318.8 & \multirow[t]{2}{*}{0.337} \\
\hline Female & 68 & -614.6 & 340.9 & \\
\hline \multicolumn{5}{|l|}{ Diagnosis } \\
\hline$\beta$-Thalassemia major & 101 & -605.0 & 279.1 & \multirow[t]{4}{*}{0.244} \\
\hline$\beta$-Thalassemia intermediate & 1 & -3338.0 & NA & \\
\hline Sickle/ß-Thalassemia & 4 & -2120.5 & 958.3 & \\
\hline Sickle cell anemia & 18 & -1604.9 & 270.1 & \\
\hline \multicolumn{5}{|l|}{ Splenectomy } \\
\hline Yes & 53 & -1066.5 & 389.7 & \multirow[t]{2}{*}{0.37} \\
\hline No & 71 & -637.9 & 292.4 & \\
\hline \multicolumn{5}{|l|}{ Chelation therapy } \\
\hline Concomitant use of DFO & 40 & -213.5 & 355.1 & \multirow[t]{2}{*}{0.075} \\
\hline DFX as a single agent & 84 & -1110.4 & 300.7 & \\
\hline \multicolumn{5}{|l|}{ DFX Dose $(\mathrm{mg} / \mathrm{kg})$} \\
\hline$<30$ & 19 & -1160.4 & 484.3 & \multirow[t]{3}{*}{0.736} \\
\hline $30-39$ & 71 & -848.0 & 275.1 & \\
\hline$\geq 40$ & 34 & -575.3 & 588.1 & \\
\hline \multicolumn{5}{|l|}{ Initial ferritin } \\
\hline$<3000$ & 32 & 115.7 & 288.3 & \multirow[t]{2}{*}{0.003} \\
\hline$\geq 3000$ & 92 & -1146.9 & 295.0 & \\
\hline \multicolumn{5}{|l|}{ No. of transfusions per year } \\
\hline $0-6$ & 11 & -1796.2 & 360.2 & \multirow[t]{4}{*}{$0.48 \mathrm{C}$} \\
\hline $7-12$ & 23 & -848.6 & 371.7 & \\
\hline $13-18$ & 69 & -829.1 & 359.9 & \\
\hline$>18$ & 21 & -254.0 & 576.6 & \\
\hline
\end{tabular}

When a multivariate analysis in a model including age group, age at starting DFX, diagnostic category, concurrent chelation, and initial ferritin was performed, it was found that none was significant except initial ferritin in excess of $3000 \mathrm{ng} / \mathrm{ml}(\mathrm{p}=0.04)$.

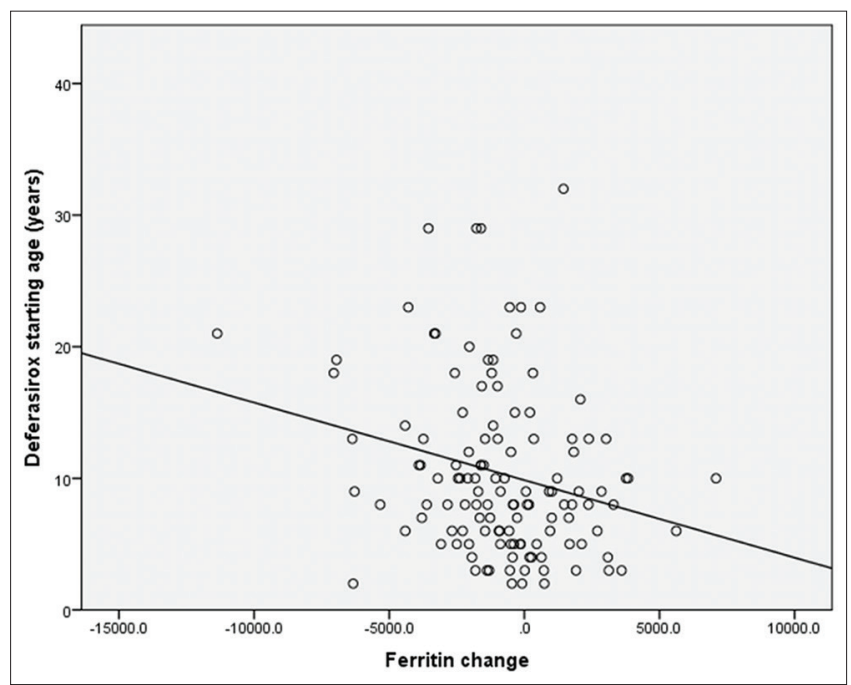

Figure 2: Correlation between age at starting Deferasirox and changes in serum ferritin in 124 complaint patients

\section{Discussion}

Oral iron chelators including Deferasirox had changed the prospects of iron chelation in hemoglobinopathies. In the current cohort nearly four-fifth of the enrolled patients were compliant with the DFX therapy, such a high rate of compliance is not unexpected and has been attributed by previous researchers to greater convenience (37\%) compared to deferoxamine, absence of injection-site soreness $(25 \%)$, and minor disruption of their daily activity (23\%) [9]. Furthermore, it is associated with longer halflife and more limited side effects when compared to the other oral iron chelator Defriprone [4]. Furthermore, it was documented that once-daily appropriate dosing with deferasirox provides a sustained reduction in labile pool iron levels in heavily iron-overloaded patients, and thus may reduce unregulated tissue iron loading and prevents further end-organ damage [10], [11], [12].

The study showed a significant reduction in serum ferritin level with the administration of DFX with a mean difference: $-821.1 \mathrm{ng} / \mathrm{ml}$, after a median of 2.1 years in complaint patients. In the ESCALATOR study, which is a prospective, open-label multicenter trial conducted at seven sites in the Middle East, including 237 patients aged $2-42$ years with $\beta$-thalassemia and transfusional iron overload, documented a median reduction in ferritin of $-341 \mathrm{ng} / \mathrm{ml}$ and $-929 \mathrm{ng} / \mathrm{ml}$ after 1 and 2 years, respectively [13], [14]. The latter figure was to a great extent comparable to our results. Another prospective multicenter study "The EPIC study" including 1744 patients from 23 countries, most of whom being hemoglobinopathies reported a significant reduction in serum ferritin from baseline $(-264 \mathrm{ng} / \mathrm{mL})$ after 1 year of follow-up [5]. Abdul-Hassan et al. (2019) in their study on 93 chelation naive hemoglobinopathy patients aged 2-5 years from Basra in Southern Iraq, reported a reduction in the mean serum ferritin of $-596.75 \mathrm{ng} / \mathrm{ml}$, after a 2 year follow-up [7]. Other studies, with longer follow-up period on deferasirox in patients with hemoglobinopathy, reported even higher reductions of their serum ferritin $[15,16]$.

On dividing the compliant patients according to their initial serum ferritin level into two groups; $\geq 3000$ $(n=92)$ and $<3000 \mathrm{ng} / \mathrm{ml}(\mathrm{n}=32)$, we found that the reduction was significant more among patients whose serum ferritin level is $\geq 3000 \mathrm{ng} / \mathrm{ml}$, by both univariate and multivariate analysis. This result may be due to more aggressive treatment at a higher level of serum ferritin. As $30.4 \%$ of patients of the former group received a dose of $40 \mathrm{mg} / \mathrm{kg} /$ day of DFX versus $12.5 \%$ of patients of the latter group; also $29.4 \%$ of the former group and $9.4 \%$ of the latter group were on combined treatment with DFX and DFO. This result is also shared by Porter et al. who showed a more pronounced response among those with greater iron overload [17].

There was a significant reduction in serum ferritin levels among patients with age groups between $>16$ years old, as compared to younger ones. The result was the obtained overall and among compliant patients. A similar finding was reported in the ESCALATOR study [13]. The patients in the latter study were classified 
as pediatrics aged ( $<16$ year) and adults as aged $(\geq 16$ year), and it was documented that the reduction was more among adults than it was in children.

A greater reduction in serum ferritin level was found in the current study among splenectomized (mean reduction $-750.8 \mathrm{ng} / \mathrm{ml}$ ) compared to nonsplenectomized (mean reduction -277.5 ng/ml), but the reduction was not significant. This is similar to the observations of Cohen et al. who found that splenectomized patients on chelation therapy had lower transfusional iron intake and greater reduction in iron stores than patients with intact spleens [18].

The current study also included following S. creatinine and ALT prior therapy and at last follow-up. The absence of significant change in S. creatinine after a median of 2 years of therapy is contrary to that reported by others where an increase was documented after therapy [7], [19]. Likewise, our study did not document any significant change in ALT, which is consistent with some studies but is contrary to others [7], [20], [21].

\section{Conclusions}

Deferasirox was effective in reducing the level of serum ferritin among this cohort of hemoglobinopathy patients, to a degree comparable to that reported in other studies worldwide. Furthermore, there was a significant association between the reduction of serum ferritin level and the age, timing of treatment, drug compliance, and the initial serum ferritin level.

\section{References}

1. KohneE. Hemoglobinopathies:Clinicalmanifestations, diagnosis, and treatment. Dtsch Arztebl Int. 2011;108(31-32):532-40.

PMid:21886666

2. Hoffbrand AV, Taher A, Cappellini MD. How I treat transfusional iron overload. Blood. 2012;120(18):3657-69. https://doi. org/10.1182/blood-2012-05-370098

PMid:22919029

3. Breuer W, Hershko C, Cabantchik ZI. The importance of non-transferrin bound iron in disorders of iron metabolism. Transfus Sci. 2000;23(3):185-92. https://doi.org/10.1016/ s0955-3886(00)00087-4

PMid:11099894

4. Saliba AN, Harb AR, Taher AT. Iron chelation therapy in transfusion-dependent thalassemia patients: Current strategies and future directions. J Blood Med. 2015;6:197-209. https://doi. org/10.2147/jbm.s72463

PMid:26124688

5. Cappellini MD, Porter J, El-Beshlawy A, Li CK, Seymour JF, Elalfy $\mathrm{M}$, et al. Tailoring iron chelation by iron intake and serum ferritin: The prospective EPIC study of deferasirox in 1744 patients with transfusion-dependent anemias. Haematologica. 2010;95(4):557-66. https://doi.org/10.3324/ haematol.2009.014696

PMid:19951979

6. Moukalled NM, Bou-Fakhredin R, Taher AT. Deferasirox: Over a decade of experience in thalassemia. Mediterr $\mathrm{J}$ Hematol Infect Dis. 2018;10(1):e2018066. https://doi.org/10.4084/ mjhid.2018.066

PMid:30416698

7. Abdul-Hassan BA, Hassan MK, Jaber RZ. Deferasirox in chelation naïve children with transfusional iron overload in Basra, Iraq: A two-year single center study. Iran J Blood Cancer. 2019;11(4):115-22.

8. Mohsin AM, Hassan MK. A 3-year study of deferasirox therapy in sickle cell disease patients in Basra, Southern Iraq. Niger J Clin Pract. 2018;21(6):735-42. https://doi.org/10.4103/njcp. njcp_162_17

PMid:29888721

9. Cappellini MD, Zanaboni L. Efficacy and safety of deferasirox. Transfusion iron chelation therapy, US hematology. Touch Brief. 2009;107(9):68-73

10. Cabantchik ZI, Breuer W, Zanninelli G, Cianciulli P. LPI-labile plasma iron in iron overload. Best Pract Res Clin Haematol. 2005;18(2):277-87. https://doi.org/10.1016/j.beha.2004.10.003 PMid: 15737890

11. Daar S, Taher A, Pathare A. Deferasirox (Exjade, ICL670) provides 24 hour protection from labile plasma iron (LPI), in iron overloaded $\beta$-thalassaemia patients previously chelated with mono- or combination therapy. Haematologica. 2006;91(Suppl 1):31. https://doi.org/10.1182/blood.v108.11.1773.1773

12. Daar $S$, Pathare A, Nick $H$, Kriemler-Krahn U, Hmissi A, Habr D, et al. Reduction in labile plasma iron during treatment with deferasirox, a once-daily oral iron chelator, in heavily iron-overloaded patients with betathalassaemia. Eur J Haematol. 2009;82(6):454-7. https://doi. org/10.1111/j.1600-0609.2008.01204.x

PMid:19191863

13. Taher A, El-Beshlawy A, Elalfy MS, Al Zir K, Daar S, Habr D, et al. Efficacy and safety of deferasirox, an oral iron chelator, in heavily iron-overloaded patients with beta-thalassaemia: The ESCALATOR study. Eur J Haematol. 2009;82(6):458-65. https://doi.org/10.1111/j.1600-0609.2009.01228.x PMid:19187278

14. Taher A, Elalfy MS, Al Zir K, Daar S, Al Jefri A, Habr D, et al. Importance of optimal dosing $\geq 30 \mathrm{mg} / \mathrm{kg} / \mathrm{d}$ during deferasirox treatment: 2.7-yr follow-up from the ESCALATOR study in patients with $\beta$-thalassaemia. Eur J Haematol. 2011;87(4):355-65. https://doi.org/10.1111/j.1600-0609.2011.01662.x PMid:21668502

15. Pennell DJ, Porter JB, Cappellini MD, Chan LL, El-Beshlawy A, Aydinok $\mathrm{Y}$, et al. Deferasirox for up to 3 years leads to continued improvement of myocardial $\mathrm{T} 2{ }^{*}$ in patients with $\beta$-thalassemia major. Haematologica. 2012;97(6):842-8. https://doi. org/10.3324/haematol.2011.049957

PMid:22271905

16. Cappellini MD, Bejaoui M, Agaoglu L, Canatan D, Capra M, Cohen A, et al. Iron chelation with deferasirox in adult and pediatric patients with thalassemia major: Efficacy and safety during 5 years' follow-up. Blood. 2011;118(4):884-93. https://doi. org/10.1182/blood-2011-09-377929 PMid:21628399

17. Porter JB, Elalfy MS, Taher AT, Aydinok Y, Chan LL, Lee SH et al. Efficacy and safety of deferasirox at low and high iron burdens: Results from the EPIC magnetic resonance imaging substudy. Ann Hematol. 2013;92(2):211-9. https://doi. 
org/10.1007/s00277-012-1588-x

PMid:23086508

18. Cohen AR, Glimm E, Porter JB. Effect of transfusional iron intake on response to chelation therapy in beta-thalassemia major. Blood. 2008;111(2):583-7. https://doi.org/10.1182/ blood-2007-08-109306

PMid:17951527

19. Antmen B, Karakaş Z, Yeşilipek MA, Küpesiz OA, Şaşmaz I, Uygun $V$, et al. Deferasirox in children with transfusiondependent thalassemia or sickle cell anemia: A large cohort reallife experience from Turkey (REACH-THEM). Eur J Haematol. 2018;102(2):123-30. https://doi.org/10.4084/mjhid.2014.025
PMid:30300449

20. Soliman A, Yassin M, Al Yafei F, Al-Naimi L, Almarri N, Sabt A, et al. Longitudinal study on liver functions in patients with thalassemia major before and after deferasirox (DFX) therapy. Mediterr J Hematol Infect Dis. 2014;6(1):e2014025. https://doi. org/10.4084/mjhid.2014.025

PMid:24803998

21. Ejaz MS, Baloch S, Arif F. Efficacy and adverse effects of oral chelating therapy (deferasirox) in multi-transfused Pakistani children with $\beta$-thalassemia major. Pak J Med Sci. 2015;31(3):621-5. https://doi.org/10.12669/pjms.313.6972 PMid:26150856 